\title{
Behavioral Bias in Individual Investment Decisions: Is It a Common Phenomenon in Stock Markets?
}

\author{
Nawal Hussein Abbas Elhussein ${ }^{1}$ \& Jarel Nabi Ahmed Abdelgadir ${ }^{2}$ \\ ${ }^{1}$ School of Management Studies, University of Khartoum, Khartoum, Sudan \\ ${ }^{2}$ Ahfad University for Women, Khartoum, Sudan \\ Correspondence: Nawal Hussein Abbas Elhussein, Mississauga, Ontario, L5B 3Z1, Canada. Tel: 1-289-724-2722. \\ E-mail: nawalelhussein80@gmail.com
}

Received: July 27, 2020

doi:10.5430/ijfr.v11n6p25
Accepted: September 14, 2020

Online Published: November 30, 2020

URL: https://doi.org/10.5430/ijfr.v11n6p25

\begin{abstract}
This paper aims to investigate the behavioral factors that influence individual investment decision making at a developing country stock market; the Sudanese Stock Exchange Market. The Study employs a cross-sectional survey design as well as analytical methods to collect the necessary data and establish the relationship between the study variables. Data is collected through a structured questionnaire from a sample of 203 individual investors and Correlation and Regression methods are used to conduct the analysis. The findings of the paper provide evidence that behavioral biases play a noticeable role in individual investment decision making process regardless of the degree of development of the stock market. The paper demonstrates that heuristic and market factors play a dominant role in the process of individual decision making in the Khartoum Stock Exchange. The factors that have a significant impact on individual investment decision making process include Representativeness, Overconfidence, Anchoring, Historical cost of stock, Customer preferences, Loss aversion, Mental accounting, Other investors' trading volume, and Quick reaction to changes in other investors 'decisions. Factors that have an insignificant impact include Availability bias, Change in stock prices, Regret aversion, and Other investors' decisions and choices.
\end{abstract}

Keywords: behavioral bias, herd behavior, heuristic bias, market factors, prospect theory

\section{Introduction}

Since the mid-1950s, the field of finance has been dominated by the traditional Finance model. Traditional finance, also referred to as standard finance is based on theories and principles founded on the premise that investors behave rationally and, thus, have focused on models that assume rationality. According to these theories, specifically, the arbitrage principles of Modigliani and Miller; the portfolio principles of Markowitz; the capital asset pricing theory of Sharpe, Lintner, and Black; and the efficient market hypothesis of Fama, markets are efficient and investors behave rationally when making their investment decisions. The essence of traditional finance is then the availability of information which is incorporated in prices of financial assets and risk-averse investors who base their financial decisions on risk-return tradeoff. However, the repetitive financial crises and the various stock market anomalies, which remained unanswered render the market efficiency hypothesis and rationality of investors questionable. In 1979 Daniel Kahneman and Amos Tversky published their most important work titled "Prospect Theory: An analysis of decision under risk", in which they criticize expected utility theory as a descriptive model of decision making under risk and develop an alternative model called Prospect Theory. Their theory explains the apparent irregularity in human behavior when assessing risk under uncertainty. They negate the notions of efficient market and investors who are rational and consistently risk-averse, paving the way to a new academic discipline; Behavioral Finance.

The pioneers of behavior finance are the psychologist Daniel Kahneman and economist Vernon Smith, who are awarded Nobel Prize in Economics in 2002. Kahneman studied human judgment and decision making under uncertainty, while Smith studied alternative market mechanisms through experimental research. Behavioral finance combines the disciplines of psychology and economics to explain why and how people make irrational, suboptimal financial decisions and elucidate ramifications of such decisions on the efficiency of capital markets, personal wealth, and the performance of corporations. It asserts that the investment decision-making process is influenced by various, unavoidable behavioral biases and that human brains process information using shortcuts and emotional filters even in investment decisions. Thus according to behavioral finance psychological dimensions influence the investment 
decision making process. As stated by Pompian (2006), instead of a universal theory of investment behavior, behavioral finance research relies on a broad collection of evidence pointing to the ineffectiveness of human decision making in various economic decision-making circumstances. Though the traditional finance field is reluctant to accept the view of psychologists, the later has succeeded in providing answers and explanations to some of the reasons that induce investors to deviate from rational financial decision-making and the sudden and untimely changes in the stock market pricing of securities. The studies reveal that some of the irrational behaviors in the market place include excessive trading, buying and selling stocks without considering their fundamental values, basing decisions on stocks past performance and what others buy and sell and retain loss-making stocks, while selling winning stocks. The behavioral biases researched incorporate Overconfidence, Disposition Effect, Representativeness, Anchoring, Availability, Herd Behavior, and Home Bias.

Most of those researches are carried out in developed American, European, and Asian markets. There is a dearth of research in this area in developing countries, specifically in Middle Eastern and North African markets. Further, the majority of empirical studies are based on secondary data that have been generally collected from discount brokerage house firms or from different databases and are longitudinal in nature. The studies that are based on primary data or that are qualitative in nature are few in number. According to Kumar and Goyal 2015, 75 out of 94 studies are conducted in developed countries and only 21 out of the total of 117 studies are based on primary data. In addition, the majority of past research investigates the impact of either a single bias or a limited number of biases on individuals' behavior. Thus since behavioral biases stem from the fact that a considerably huge number of financial decisions are a result of the interaction of social and psychological factors, studies conducted in Western context cannot be generalized to developing countries. This paper attempts to fill the gap by investigating the impact of a set of behavioral factors on individual investment decision making in an African developing country; Sudan, using primary data-based empirical research. The rest of the paper is organized as follows: Section two provides a review of the empirical studies concerning the impact of behavioral biases on investment decision making in securities markets. Section three describes the methodology followed and the methods of analysis employed. Section four presents the empirical results and their discussion. Section five concludes the paper.

\section{Literature Review}

The concern about establishing an organized stock exchange in Sudan dates back to the early nineteen sixties. The Stock Exchange Act of 1982 establishes the stock exchange as a department in the Bank of Sudan, which is expected to function under the control of the Ministry of Finance and Economic Planning. However, many years elapsed before the sincere efforts for establishing an organized stock exchange in Sudan turned to be a reality. The Khartoum Stock Exchange (KSE) Act 1994, abolishing that of 1982, was passed in 1994, and finally, after a search for a stock exchange that goes back over thirty years, Sudan has its first ever stock exchange, which has been in operation for more than 26 years by the end of 2019.

According to behavioral finance scholars, individuals have unavoidable psychological biases that preclude them from making rational investment decisions and negatively affect the market efficiency. Several studies have demonstrated that, in reality, markets are inefficient which is evidenced by the persistence of anomalies. Bounded rationality, cognitive and emotional biases, fundamental heuristics, intuitive reasoning and limited information and reliance on historical performance, past experiences and expectations are cited as causes for irrational behavior and inefficiency (Baker and Nofsinger 2002; Shefrin 2006; Ajmal et al 2011; Bondt et al 2013; Sahietal 2013; Bakar et al 2016). Research on the impact of behavioral biases on individuals' decisions regarding security trading has generally concentrated on six common biases that affect the investment decision-making process, namely, overconfidence, disposition effect, herding bias, representativeness, anchoring, and availability bias. Additionally, most of the studies examine the impact of a limited number of biases on the individual decision making process. For instance research on overconfidence reveals that this bias negatively affects investment decisions (Gervais et al 2001; Statman et al 2006; Chen 2007; Grinblatt and Keloharju 2009; Shah et al 2012; Bashir et al 2013; Oprean (2014); Kafayat 2014); Bakar and Yi (2015) and Geetika and Singh (2019). Representativeness bias as asserted by Irshad et al (2016) and Ikram (2016) positively affects the trading decisions of individual investors. However other studies report a negative relationship between representativeness bias and investment decision making (Chen 2007; Shah et al 2012; Athur 2014; Onsomu 2014; Yaowen et al 2015 and Toma 2015. Disposition effect has been researched by Dhar and Zhu (2006), Frazzini (2006), Chen (2008), Barberis and Xiong 2009, Toma (2015), and Geetika and Singh (2019). The evidence arrived at is mixed, some studies report no effect on trading decisions, while others document insignificant impact. Similarly studies on the impact of herding behavior (Demirer and Kutan (2006); Andrikopoulos et al (2014); Balcilar and Demirer (2015); Huang et al. (2015); Galariotis et al (2016); Metawa et al (2018) and Geetika and Singh, (2019), show no evidence and partial evidence of the influence of herding bias on the process of decision making by 
individual investors. Anchoring bias as proclaimed by Shah et al (2012) has a negative impact on the decision making process, whereas Geetika and Singh, (2019) suggest no effect of this bias. The evidence reported on availability bias varies; Shah et al (2012) document a negative effect, whereas Bakar and Yi (2015) find a significant impact. Studies that have incorporated an array of behavioral factors are few in number (Chandra and Kumar 2012; Kengatharan and Kengatharan 2014; Bakar and Yi, 2016). According to Chandra and Kumar behavioral biases do influence individual investment decision making process. Their findings affirm that heuristic factors such as anchoring, availability bias, and regret aversion are dominant compared to factors suggested under prospect theory such as loss aversion. Kengatharan and Kengatharan results show that there are four behavioral factors affecting the investment decisions of individual investors; herding, heuristics, prospect, and market and that all factors have a moderate impact, whereas anchoring has a high influence and choice of stock has a low influence on investment decision. The findings of Bakar and Yi show that overconfidence, conservatism, and availability bias have a significant impact on the investors' decision making process, while herding behavior has no significant impact.

The most popular and widely used statistical technique in these studies is the regression analysis. Various types of regressions such ordinary least squares, linear regression, logistic regression, and polynomial regression are utilized. Some studies employ a combination of techniques such as analysis of variance, chi-square, t-statistics and structural equation modelling.

Based on the literature review and the characteristics of KSE, the following hypotheses have been set for variables selected as proxies for each of the four groups of the behavioral factors.

Herding Factors:

H1: There is no impact of other investors' choice on the process of individual investment decision making.

$\mathrm{H} 2$ : There is a significant impact of other investors' trading volume on the process of individual investment decision making.

H3: There is no impact of other investors' buying and selling decisions on the process of individual investment decision making.

H4: There is significant impact of quick reaction to changes of other investors 'decisions on the process of individual investment decision making.

Heuristic Factors:

H5: There is an insignificant impact of availability bias on the process of individual investment decision making.

H6: There is a significant impact of representativeness on the process of individual investment decision making.

H7: There is a significant impact of overconfidence on the process of individual investment decision making.

H8: There is a significant impact of anchoring on the process of individual investment decision making.

Prospect Factors:

H9: There is a significant impact of loss aversion on the process of individual investment decision making.

H10: There is no impact of regret aversion on the process of individual investment decision making.

H11: There is an impact of mental accounting on the process of individual investment decision making

Market factors:

H12: There is no impact of changes in stock prices on the process of individual investment decision making.

H13: There is a significant impact of customer preferences on the process of individual investment decision making.

H14: There is a significant impact of historical stock prices on the process of individual investment decision making.

\section{Material and Methods}

The paper employs a cross-sectional survey research design and depends mainly on primary data, which is collected through a structured questionnaire. The targeted population is the individual investors trading in Khartoum Stock Exchange. A sample of 204 active investors has been chosen.

The questionnaire consists of five sections. In the first section the respondents are requested to provide personal background information. The second section contains statements that are used as measures of heuristic biases, which include representativeness, overconfidence, anchoring, locality bias, and availability. In the third section statements relating to stock choice, buying and selling of stocks and overreaction to stock price changes, which are used as 
proxies of herding bias. The third section contains the statements that refer to prospect biases, namely, Loss aversion, regret aversion, and mental accounting. Items that relate to market factors such as historical cost of stocks, changes in stock prices, and customer preferences are the subject of the last section of the questionnaire. All items in the questionnaire are responded to using a five-point Likert scale from 1 (strongly disagree) to 5 (strongly agree). First, the validity and reliability of the instrument are checked through conducting a pilot test and testing the correlation by using the Cronbanch Alpha test. The impact levels of behavioral finance factors on the individual investment decisions making are identified by calculating the values of sample mean of each variable. Because 5- point lickertscales are used to measure the impact levels of these variables, the impact of the mean values of these variables are decided based on the following rules:1-Mean values less than 3 show that the variables have low impact, 2-Mean values from 3 to 4 show that the variables have a moderate impact, 3-Mean values from 4 to 5 indicate that the variables have high impact and 4-Mean values that are more than 5 demonstrate that the variables have very high impact. Further the paper uses factor analysis to simplify the data and reduce the number of variables in the regression model. The factor analysis is carried out following the assumptions recommended by Hair et al. (2010); there must be sufficient number of statistically significant correlations in the matrix., Kaiser-Meyer-Olkin (KMO) measure of sampling adequacy should be at least 0.6, Bartlett's test of sphericity should be significant at 0.05 , communalities of items should be greater than 0.50., the minimum requirement of factor loading 0.50 , based on 0.05 significant level, with value of cross loading 0.50 and above, and eigen values should be more than 1 .

The data collected is processed and analyzed using SPSS software. To test the relationship between behavioral biases and individual investor decision making, the multiple regression analysis is adopted. Initially the data has been examined for normality, linearity, multicollinearity, and homoscedasticity. Correlation analysis is employed to establish the degree of correlation between the variables of the study.

\section{Results and Discussion}

A total of 203 out of 204 questionnaires are received from the respondents, with an overall response rate of $99.5 \%$. The results of Cronbach's Alpha value as shown in Table 1 indicate that all factors have values greater than 0.6, which implies that the measures have an acceptable level of reliability.

Table 1. Reliability Test

\begin{tabular}{lccc}
\hline Construct & Variable & No of items & Cronbach's alpha \\
\hline Behavioral bias Groups & Herding & 4 & .888 \\
& Heuristic & 6 & .852 \\
& Market & 5 & .842 \\
& Prospect & 3 & .614 \\
Behavioral bias factors & & 18 & .896 \\
Investment decision & & 11 & .826 \\
Overall Items & & 29 & .917 \\
\hline
\end{tabular}

The statistics for the demographic characteristics of the sample are displayed in Table 2.

Table 2. Respondents' profile

\begin{tabular}{llrl}
\hline Variable & Category & Frequency & $\%$ \\
\hline \multirow{3}{*}{ Gender } & Male & 132 & 65 \\
& Female & 71 & 35 \\
Respondent's age & $20-25$ year & 37 & 18 \\
& $26-30$ & 59 & 29 \\
& $31-35$ & 72 & 36 \\
\hline
\end{tabular}




\begin{tabular}{llcc}
\hline & Above 40 years & 35 & 17 \\
Marital status & Married & 123 & 61 \\
& Single & 80 & 39 \\
Educational & High school & 14 & 7 \\
& Diploma & 15 & 7 \\
& Bachelor degree & 96 & 45 \\
Years of experience & Master & 74 & 40 \\
& PhD & 4 & 1 \\
& 5 -10 years than 5 years & 93 & 46 \\
& More than 10 years & 70 & 34 \\
& & 40 & 20 \\
\hline
\end{tabular}

The sample for the research is composed of $65 \%$ male and $35 \%$ female investors. This composition of sample symbolizes the cultural and social norms of Sudan, where there is a deep rooted notion that the workplace is still a male playground and women participation in the work force is still lagging behind. In terms of age groups $83 \%$ of the respondents are within the range of 20 to 35 years. Only $17 \%$ are above 40 years. This may reflect a better awareness of youth population about the benefits of investing in stock exchanges and their increased savings compared to aging population. In terms of qualification, the majority of the sample; $85 \%$, hold either a bachelor's degree, $45 \%$ or a master degree $40 \%$. As regarding years of trading experience, $46 \%$ of the sample has less than 5 years of experience, 34 percent 5 to 10 years of experience and $20 \%$ more than 10 years of experience. The descriptive statistics of qualification and experience appear to be in line with the age characteristics of the respondents, which reflect the dominance of youth population.

Using factor analysis the twenty one items suggested to measure the construct are reduced to eighteen items. All the remaining items have factor loading values above the minimum values of 0.50 , with value of cross loading less than 0.50. The first factor of the construct captures all the items of herding factors (Other investors' choice, Other investors' trading volume, Other investors' buying and selling decisions, and Quick reaction to changes of other investors 'decisions). The second factor captures six items of heuristic factors (Representativeness, Overconfidence, Anchoring, and Availability bias). The third factor captures three items of market factors (changes in stock prices, customers' preference and historical cost of stock). The fourth factor of the construct captures all the items of prospect factors (Loss aversion, Regret aversion, Mental accounting).

Table (4.3) shows that the items for the construct loaded on the four factors; herding factors, heuristic factors, market factors and prospect factors have eigenvalues exceeding 1.0 (6.836, 2.091, 1.794, and 1.214 respectively). The factor loading of the construct items on the four factors ranged from 0.517 to 0.873 . The four factors explain $66.311 \%$ of variance in the data.

Table 3. Factor analysis

\begin{tabular}{|c|c|c|c|c|}
\hline \multirow[t]{2}{*}{ Variables } & \multicolumn{4}{|c|}{ Components } \\
\hline & 1 & 2 & 3 & 4 \\
\hline ther investors' decisions of buying and selling stocks have impact on your & .873 & .161 & .145 & .100 \\
\hline $\begin{array}{l}\text { investment decisions. } \\
\text { Other investors' decisions of the stock volume have impact on your investment }\end{array}$ & .836 & .135 & .106 & .112 \\
\hline $\begin{array}{l}\text { decisions. } \\
\text { You usually react quickly to the changes of other investors 'decisions and follow }\end{array}$ & .787 & .185 & 172 & -.156 \\
\hline $\begin{array}{l}\text { their reactions to the stock market. } \\
\text { Other investors' decisions of choosing stock types have impact on your investment } \\
\text { decisions. } \\
\text { You rely on your previous experiences in the market for your next investment. }\end{array}$ & .770 & .198 & $\begin{array}{l}.128 \\
-.005\end{array}$ & $\begin{array}{l}.105 \\
.152\end{array}$ \\
\hline
\end{tabular}


Investors prefer local markets to international markets because they are more .088

.785

.137

.037

knowledgeable for it.

Investors prefer local markets to international markets because they believe them to .180 be safer.

You believe that your skills and knowledge of stock market can help you to.273 outperform the market.

Investors prefer to invest in local companies because of the easy access to.095 information.

You forecast the changes in stock prices in the future based on the recent stock.262

prices.

.068

$.703 \quad .086 \quad .085$

Investors are carefully looking at changes in stock prices they want to invest in.

$.351 \quad .073 \quad .109$

You analyze the companies' customer preference before you invest in their stocks.

Investors depend on the original purchase cost when making a sale decision or when.234

analyzing the trends of listed securities.

.084

$.359 \quad .758 \quad-.086$

$.212 \quad .683 \quad .111$

Investors prefer active securities.

Investors are familiar with the fundamentals of dealing with the market when $.362 \quad \begin{array}{lll}.015 & .632 & .244\end{array}$

making investment decisions on securities.

$.424 \quad .260 \quad .025 \quad .635$

Investors feels regret when holding long term losing securities.

Investors deal with investment decisions separately and ignore the interdependence ${ }^{.-15}$

of those decisions.

Investors deal with investment decisions separately and ignore the interdependence

of those decisions.

You avoid selling shares that have decreased in value and readily sell shares that

have increased in value.

Eigenvalues

Percentage of Variance Explained

Percentage of Variance Explained

Total Variance Explained (\%)

.-155

$.021 \quad .226 \quad .802$

$424 \quad .260 \quad .025 \quad .635$

Kaiser-Meyer-Olkin (KMO)

Bartlett's Test of Sphericity

Table 4 presents the descriptive statistics of the selected behavioral factors. The statistics indicate that the impact of the selected behavioral variables on the individual investment decision making ranges between a moderate and high impact; the mean takes values between 3.8 and 4.3 .

Table 4. Impact of behavioral factors on the investment decision making

\begin{tabular}{lll}
\hline Herding Factors: & Mean & Standard Deviation \\
\hline $\begin{array}{l}\text { Other investors' choice } \\
\begin{array}{l}\text { Other investors' buying and selling } \\
\text { decisions }\end{array}\end{array}$ & 3.9343 & 0.98833 \\
\hline $\begin{array}{l}\text { Reaction to changes of other } \\
\text { investors' decisions }\end{array}$ & 3.8357 & 3.60550 \\
\hline $\begin{array}{l}\text { Over-reaction to price changes of } \\
\text { stocks }\end{array}$ & 4.2254 & 1.11009 \\
\hline Heuristic factors: & 3.8404 & 0.73067 \\
\hline Representativeness & 4.1315 & \\
\hline Locality bias. & 3.9812 & 0.81934 \\
\hline Overconfidence & 4.1690 & 0.91095 \\
\hline Availability bias & 4.0798 & 0.75834 \\
\hline Anchoring & & 0.76369 \\
\hline
\end{tabular}




\begin{tabular}{lcc}
\hline Prospect factors: & & \\
\hline Regret aversion & 4.1831 & 0.96607 \\
\hline Loss aversion & 3.8169 & 1.11562 \\
\hline Mental accounting & 4.0235 & 0.86024 \\
\hline Market factors: & & 0.82677 \\
\hline Historical cost of stocks & 4.2066 & 0.74320 \\
\hline Changes in stocks prices & 4.2817 & 0.88220 \\
\hline Customer preferences & 4.0047 & \\
\hline
\end{tabular}

The Correlation analysis has been conducted after testing the data for normality, linearity, multicollinearity, and homoscedasticity. The normality has been established through the relevant histograms, which shows that most values fall in the center and the curves take the bell-shape. The normal probability plots also show that the residual points are close to the diagonal line. Therefore, the variables are normally distributed. No curvilinear pattern of relationship is apparent from the scatter plots, hence there is no violation of the assumption of linearity. Heteroscedasticidity is checked through the scatter plots of standardized residual. The residual plots take roughly the rectangular shape, which indicates that there is no problem of heteroscedasticidity in the data. The result of Multicollinearity test indicates that all values of the Variance Inflation Factors (VIF) are less than the threshold of 10, all Tolerance values are more than 0.1 . This indicates that, there is no multicollinearity in the data.

As shown in Table 5 below the correlation analysis reveals strong association between all the variables of the study. The four behavioral factors are positively and significantly correlated with each other and with the dependent variable. Herding factors are positively and significantly correlated with heuristic factors $(\mathrm{r}=.418, \mathrm{p}<0.01)$, market factors $(\mathrm{r}=.428, \mathrm{p}<0.01)$, prospect factors $(\mathrm{r}=.313, \mathrm{p}<0.01)$, and investment decision $(\mathrm{r}=.443, \mathrm{p}<0.01)$. Heuristic factors are positively and significantly correlated with market factors $(\mathrm{r}=.494, \mathrm{p}<0.01)$, prospect factors $(\mathrm{r}=.889, \mathrm{p}$ $<0.01)$ and investment decision $(\mathrm{r}=.441, \mathrm{p}<0.01)$. As regarding the market factors the results show positive and significant association between them and the prospect factors $(\mathrm{r}=.457, \mathrm{p}<0.01)$ and investment decision $(\mathrm{r}=.635, \mathrm{p}$ $<0.01)$, while prospect factors is positively and significantly correlated with investment decision $(\mathrm{r}=.333, \mathrm{p}<0.01)$.

Table 5. Person's correlation coefficients

\begin{tabular}{lccccc}
\hline \multicolumn{1}{c}{ Variables } & 1 & 2 & 3 & 4 & 5 \\
Herding factors & 1 & & & & \\
Heuristic factors & $.418^{* *}$ & 1 & & & \\
Market factors & $.428^{* *}$ & $.494^{* *}$ & 1 & & \\
Prospect factors & $.313^{* *}$ & $.889^{* *}$ & $.457^{* *}$ & 1 & \\
Investment decision & $.443^{* *}$ & $.441^{* *}$ & $.635^{* *}$ & $.333^{* *}$ & 1 \\
\hline
\end{tabular}

* Correlation is significant at 0.05 .

** Correlation is significant at 0.01 .

The hypotheses are tested using the multiple regression analysis after data has been tested for normality, linearity, multicollinearity and homoscedasticity. The impact of the selected behavioral variables of herding, heuristic, market and prospect factors are demonstrated in Table 6.

Table 6. The effect of heuristic factors on individual investment decision making

\begin{tabular}{|c|c|c|c|c|c|}
\hline & $\begin{array}{c}\text { Unstandardized } \\
\text { Coefficients } \\
\underline{B}\end{array}$ & $\begin{array}{l}\text { Standardized } \\
\text { Coefficients } \\
\text { Std. Error }\end{array}$ & $\begin{array}{c}\text { Standardized_- } \\
\text { Coefficients Beta } \\
\end{array}$ & $\underline{T}$ - Statistics & $\underline{\text { Sig }}$ \\
\hline Herding Factors: & & & & & \\
\hline Constant & 3.222 & .153 & & 21.102 & .000 \\
\hline
\end{tabular}


Other investors' choice

.016

.052

.029

.314

.754

Other investors' trading

volume

.133

.049

.256

2.706

.007

Other investors' buying and

selling decisions

.003

.010

.023

.345

.731

Quick reaction to changes of other investors 'decisions

.041

.170

2.030

.044

Heuristic Factors:

Constant

2.501

.198

12.924

.000

Availability bias

.033

.051

.050

.656

.513

Representativeness

.096

.039

.173

2.434

.016

Overconfidence

.049

.458

5.618

.000

Anchoring

.158

.053

.221

3.017

.003

Prospect Factors:

Constant

.198

14.39

.000

Regret aversion

0.38

.078

1.174

.242

Loss aversion

.036

.151

2.091

.038

Mental accounting

.045

.319

4.519

.000

Market factors:

Constant

.250

8.42

.000

Changes in stock prices

.004

.066

.006

.066

.948

Customer preference

.140

.053

.226

2.65

.009

Historical cost of stock

.149

.056

.224

2.63

.009

According to the results of the analysis two measures of the herding factors; Other investors' trading volume and Quick reaction to changes of other investors 'decisions $(b=0.133, p=0.007$ and $b=0.084, p=0.044$ respectively) have a positive significant influence on individual investment decision making. The other two proxies, namely, Other investors' buying and selling decisions and Other investors' choice $(b=0.003, p=0.731$ and $b=0.016, p=0.754$ respectively) have a positive insignificant influence on individual investment decision making process. As regarding the impact of heuristic factors, the results indicate that Representativeness, Overconfidence and Anchoring have a positive significant influence on individual investment decision making, whereas Availability bias has a positive insignificant influence on individual investment decision making $(b=0.096, p=0.016 ; b=0.276 p=0.000 ;$ and $b=$ $0.158, p=0.003$ respectively). The impact of two elements of the prospect factors: Loss aversion and Mental accounting on individual investment decisions is positive and significant $(b=0.036, P=0.038$ and $b=0.045, P=$ 0.000 respectively), whereas Regret aversion has a positive insignificant influence $(b=0.038, P=0.242)$. With respect to the market factors, Table 6 reveals that the Historical cost of stock and Customer preferences have a 
positive significant impact on individual investment decision making $(b=0.140, p=0.009 ; b=0.149, p=0.009$ respectively). The Change in stock prices has a positive insignificant influence on individual investment decisions $(b=$ $0.04, \mathrm{p}=0.948$ ).

Table 7 provides a summary of the R-Squared values, The F- statistics, and p values pertaining to the selected behavioral factors.

Table 7. Model summary

\begin{tabular}{|c|c|c|c|c|c|c|}
\hline & $\begin{array}{l}\mathrm{R} \\
\text { Squared }\end{array}$ & $\begin{array}{l}\text { Adjusted } \\
\text { Squared }\end{array}$ & $\mathrm{R}$ & $\begin{array}{l}\text { Std. Error of } \\
\text { Estimate }\end{array}$ & F-Statistics & Sig \\
\hline Herding & .170 & .154 & & .50462 & 10.622 & 0.000 \\
\hline Heuristic & .302 & .281 & & .46501 & 14.830 & 0.000 \\
\hline Prospect & .196 & .184 & & .49538 & 16.970 & 0.000 \\
\hline Market & .383 & .365 & & .43709 & 21.100 & 0.000 \\
\hline
\end{tabular}

As Table 7 shows the R- Squared of the herding factor (0.17), implies that $17 \%$ percent of the total variance in individual investment decision making is explained by the herding biases. The F- statistics, which is equal to10.622, and $\mathrm{p}$, which is equal to 0.0000 , indicate that the model is significant. The value of the coefficient of determination of dimensions of heuristics, which is R-Squared is equal to 0.302. This result implies that $30.2 \%$ of the total variance in individual investment decision making can be explained by the dimensions of heuristics. The F- statistics and $p$ values are 14.830 and 0.0000 respectively, which shows the significance of the model. The $\mathrm{R}$ squared of the prospect factors is 0.196 , implying that $19.6 \%$ of the total variance in individual investment decision making can be explained by the prospect factors. The F- statistics, which is equal to10.622 and p, which is equal to 0.0000 indicate that the model is significant.

The R-Squared for market factors is 0.383 , suggesting that $38.3 \%$ of the total variance in individual investment decision making can be explained by the market factors. The F- statistics and p values ( 21.100 and 0.000 respectively) confirm the model's significance.

Thus the hypothesized impacts of behavioral biases on individual investment decision making, some of which are not in line with past studies results, are supported. The significant impact of overconfidence, representativeness, and quick reaction to changes of other investors 'decisions on the process of individual investment decision making reflect the informational and operational inefficiencies of KSE, which has been proven by a number of studies (Onour 2004; Onour 2010; Abbas 2010). Lack of adequate and timely information about quoted companies has led investors to depend on their own abilities in forecasting and predicting the trend of market prices and to base their decisions on their recent experience. Further, investors tend to deal with investment decisions separately and ignore the interdependence of those decisions due to insufficient or absolute information. The significant impact of anchoring and historical cost of stock on the process of individual investment decision making suggests that due to dearth of current, reliable data information that is visibly irrelevant still anchors judgments and affects guesses and predictions. The insignificant impact of herding factors is in line with past studies, which justify this finding on the basis that there are limited studies on herding bias among individual investors (Lee et al., 2004; Fernandez et al., 2011; Choi, 2013). However, the limited influence of herding bias within traders in KSE may reflect the narrow trading activity at the exchange, since individual investors tend to demonstrate herd behavior because they follow the decisions of a large group of traders. The influence of loss aversion and mental accounting on the process of individual decision making in KSE is consistent with the reasoning of the prospect theory. Investors tend to separate money into different categories and assign different risk to each category, which affects their investment decisions. As well investors have a tendency to sell well performing stocks too soon and hold on poorly performing stocks for too long.

\section{Conclusions}

The paper investigates the behavioral factors that influence individual investment decision making at the Sudanese Stock Exchange Market. The Study adopts a cross-sectional survey design and employs a number of analytical methods to validate the collected data and establish the relationship between the study variables. Data is collected through a structured questionnaire from a sample of 204 individual investors and Correlation and Regression methods are used to conduct the analysis. The paper evidence that the heuristic and market factors play a dominant 
role in the process of individual decision making (68.5\% of the variability in individual investment decision making can be explained by these factors), whereas the prospect and herding factors are responsible for the remaining inconsistency. The variables that have a significant impact on individual investment decision making in KSE include Representativeness, Overconfidence, Anchoring, Historical cost of stock, Customer preferences, Loss aversion, Mental accounting, Other investors' trading volume and Quick reaction to changes of other investors 'decisions. On the other hand Availability bias, Change in stock prices, Regret aversion, Other investors' buying and selling decisions, and Other investors' choice have an insignificant influence on the decision making process.

The findings of the paper provide evidence that behavioral biases play a noticeable role in individual investment decision making process regardless of the degree of development of the stock market. Whether in developed, emerging, or developing countries studies reveal that investors are susceptible to psychological biases when making a buy, sell, or hold decisions. Individual stock preference seems to be most affected by the amount of information available. Thus the impact of behavioral biases is expected to be more apparent in underdeveloped markets, which suffer a lack of reliable, timely information. Reliance on familiarity with a stock and past experience represents a viable way of acquiring information is such markets. Another visible difference between developed and underdeveloped markets relates to the cultural dissimilarities; for instance in developing countries, individual investors generally belong to the same geographical area and thus are more inclined to adopt herding behavior than are diversified investors in more developed markets. Further, in developed markets individual investors tend to invest in professionally managed funds, which are more prone to base decisions on pertinent information and as thus less influenced by herd behavior and the disposition effect. Though the influence of loss aversion and mental accounting on the process of individual decision making is consistent with the reasoning of the prospect theory in different markets, in less developed markets their impact is more observable. In developed markets, investors are more inclined to consider wealth in its entirety and take risks accordingly.

The outcomes of this paper would help market participants, including investors, regulators, and policymakers comprehend and consider the influence of common behavioral patterns that affect the decision making of investors in the Khartoum Stock Exchange. This will enhance the rationality of investment decisions and improve market efficiency. The research has important implications for regulators, management of the exchange, and investors. To mitigate the influence of behavioral biases information that is of better quality, timeliness, and easily accessible to investors should be of high concern. Further, there should be an enforceable requirement for total disclosure of quantitative as well as qualitative information about quoted companies. A conducive investment environment requires knowledgeable investors, which entails enhancing business education through integrating investor psychology within topics of finance. This is necessary because investors may be unfamiliar with the behavioral biases in their personalities and that such biases negatively affect their investment decisions. This recommendation would be feasible, recalling that the majority of the investors at KSE hold either a bachelor's degree; $45 \%$, or a master's degree; $40 \%$. Further, individual investors should be encouraged to employ the services of professionals and brokers to manage their investment; this will help to reduce the impact of personal biases. The management of the exchange should strive to improve the quality of financial services provided by brokerage firms through workshops and seminars that incorporate the behavioral biases of investors and how could professionals de-bias themselves and make rational investment decisions for their clients.

This study is the first one to investigate the impact of behavioral biases on individual investment decision making in the Khartoum Stock Exchange. Further research is needed to confirm the findings of this study using larger samples and respondents with greater diversity. Furthermore, future research should examine the effect of psychological factors on investment choices and market efficiency. Attempts should also be made to assess the degree of rationality of investors and detect the most influential behavioral factors that shape their investment decision making.

\section{References}

Abbas, N. (2010). Stock Market in Sudan: Thirteen Years of Experience. Khartoum University Journal of Management Studies, 3(1), 118-161.

Ajmal, S., Mufti, M., \& Shah, Z.A. (2011). Impact of Illusion of Control on Perceived Efficiency in Pakistani Financial Markets. Abasyn Journal of Social Sciences, 5(2), 100-110.

Andrikopoulos, P. A., Albin, H. A., \& Kallinterakis, V. (2014). On the Impact of Market Mergers over Herding: Evidence from EURONEXT. Review of Behavioral Finance, Leeds, 6(2), 104-135. https://doi.org/10.1108/RBF-12-07-10 
Bakar, S., \& Yi, A. N. (2016). The impact of psychological factors on investors' decision making in Malaysian stock market: a case of Klang Valley and Pahang. Procedia Economic and Finance, 35, 319-328. https://doi.org/10.1016/S2212-5671(16)00040-X

Baker, H. K., \& Nofsinger, J. R. (2002). Psychological Biases of Investors. Financial Services Review, 11(2), 97-116.

Balcilar, M., \& Demirer, R. (2015). Effect of Global Shocks and Volatility on Herd Behavior in an Emerging Market: Evidence from Borsa Istanbul. Emerging Markets Finance and Trade, 51(1), 140-159. https://doi.org/10.1080/1540496X.2015.1011520

Bashir, D. T., Javed, A., Ali, U., Meer, U. I., \& Naseem, M. M. (2013). Empirical Testing of Heuristic Interrupting the Investor's Rational Decision Making. European Scientific Journal, 9(28), 1857-7881.

Bondt, W. D., Mayoral, R. M., \& Vallelado, E. (2013). Behavioral Decision Making in Finance: An Overview and Assessment of Selected Research. Spanish Journal of Finance and Accounting, 42(157), 99-118. https://doi.org/10.1080/02102412.2013.10779742

Chandra, A., \& Kumar, R. (2012). Factors Influencing Indian Individual Investor Behavior: Survey Evidence. Decision, 39(3), 141-167. https://doi.org/10.2139/ssrn.2029642

Cohen, G., \& Kudryavtsev, A. (2012). Investor Rationality and Financial Decisions. Journal of Behavioral Finance, 13(1), 11-16. https://doi.org/10.1080/15427560.2012.653020

Demirer, R., \& Kutan, A. M. (2006). Does Herding Behavior Exist in Chinese Stock Markets? Journal of International Financial Markets, Institutions and Money, 16(2), 123-142. https://doi.org/10.1016/j.intfin.2005.01.002

Dhar, R., \& Zhu, N. (2006). Up Close and Personal: Investor Sophistication and the Disposition Effect. Management Science, 52(5), 726-740. https://doi.org/10.1287/mnsc.1040.0473

Fernandez, B. T., Garcia-Merino, R., Mayoral, V., \& Llelado, E. (2011). Herding, Information Uncertainty and Investors' cognitive profile. Qualitative Research in Financial Markets, 3(1), 7-33. https://doi.org/10.1108/17554171111124595

Fogel, O., \& Berry, T. (2006). The Disposition Effect and Individual Investor Decisions: The Roles of Regret and Counterfactual Alternatives. Journal of Behavioral Finance, 7(2) 107-116. http://dx.doi.org/10.1207/s15427579jpfm0702_5

Frazzini, A. (2006). The Disposition Effect and Underreaction to News. The Journal of Finance, 61(4), 2017-2046. https://doi.org/10.1108/17554171111124595

Galariotis, E. C., Krokida S. I., \& Spyrou, S. I. (2016). Herd Behavior and Equity Market Liquidity: Evidence from Major Markets. International Review of Financial Analysis, 48, 140-149. https://doi.org/10.1108/17554171111124595

Geetika, M., \& Singh, S. (2019). An Analysis of Behavioral Biases in Investment Decision-Making. International Journal of Financial Research, 10(4), 55-67. https://doi.org/10.5430/ijfr.v10n4p55

Gervais, S., Simon, H., \& Odean, T. (2001). Learning to be Overconfident. The Review of Financial Studies, 14(1), 1-27. https://doi.org/10.1093/rfs/14.1.1

Goodfellow, C., Bohl, M. T., \& Gebka, B. (2009). Together We Invest? Individual and Institutional Investors' Trading Behaviour in Poland. International Review of Financial Analysis, 18(4), 212-221. https://doi.org/10.1016/j.irfa.2009.03.002

Grinblatt, M., \& Keloharju, M. (2001). What makes investors trade? Journal of Finance, 56, 589-616. https://doi.org/10.1016/j.irfa.2009.03.002

Grinblatt, M., \& Keloharju, M. (2009). Sensation Seeking, Overconfidence, and Trading Activity. The Journal of Finance, 64(2), 549-578. https://doi.org/10.1111/j.1540-6261.2009.01443.x

Hair, J., Black, B., Babin, B., \& Anderson, R. (2010). Multivariate Data Analysis. Prentice Hall, Upper Saddle River, NJ.

Huang, T. C, Lin, B. H., \& Yang, T. H. (2015). Herd Behavior and Idiosyncratic Volatility. Journal of Business Research, 68(4), 763-770. https://doi.org/10.1016/j.jbusres.2014.11.025

Kafayat, A. (2014). Interrelationship of Biases: Effect Investment Decisions Ultimately. Theoretical and Applied Economics, 21(6), 85-110. 
Kahneman, D., \& Tversky, A. (1979). Prospect Theory: An Analysis of Decision under Risk. Econometrica, 47(2), 263-292. https://doi.org/10.2307/1914185

Kengatharan, L., \& Kengatharan, N. (2014). The Influence of Behavioral Factors in Making Investment Decisions and Performance: Study on Investors of Colombo Stock Exchange, Sri Lanka. Asian Journal of Finance \& Accounting, 6(1), 1-23. https://doi.org/10.5296/ajfa.v6i1.4893

Kumar, S., \& Goyal, N. (2015). Behavioral Biases in Investment Decision Making - A Systematic Literature Review. Qualitative Research in Financial Markets, 7(1), 88-108. https://doi.org/10.1108/QRFM-07-2014-0022

Lee, Y. T., Liu, Y. J., Roll, R., \& Subrahmanyam, A. (2004). Order Imbalances and Market Efficiency: Evidence from the Taiwan Stock Exchange. Journal of Financial and Quantitative Analysis, 39(2), 327-341. https://doi.org/10.1017/S0022109000003094

Massa, M., Insead, M., \& Simonov, A. (2005). Behavioral Biases and Investment. Review of Finance, 9(2), 549-572. https://doi.org/10.1007/s10679-005-4998-y

Metawa, N., Hassan, M. K., Metawa, S., \& Safa, M. F. (2018). Impact of Behavioral Factors on Investors' Financial Decisions: Case of the Egyptian Stock Market. International Journal of Islamic and Middle Eastern Finance and Management, (1), 30-55. https://doi.org/10.1108/IMEFM-12-2017-0333

Ngoc, L. T. (2014). Behavior pattern of individual investors in stock market. International Journal of Business and Management, 9(1), 1-16. https://doi.org/10.5539/ijbm.v9n1p1

Onour, I. (2004). Testing Efficiency Performance of Khartoum Stock Exchange Market. https://doi.org/10.2139/ssrn.609761

Onour, I. (2010). Testing Weak-Form Efficiency of Khartoum Stock Exchange Market. Khartoum University Journal of Management Studies, 3(2), 1-19.

Oprean, C. (2014). Effects of Behavioral Factors on Human Financial Decisions. Procedia Economics and Finance, 16, 458-463. https://doi.org/10.1016/S2212-5671(14)00825-9

Pompian, M. M. (2006). Behavioral Finance and Wealth Management: How to Build Optimal Portfolios that Account for Investor. John Wiley \& Sons, Inc., Hoboken, New Jersey.

Shah, S. F., Raza, M. W., \& Khurshid, M. R. (2012). Overconfidence and Perceived Market Efficiency. Interdisciplinary Journal of Contemporary Research in Business, 3(10), 1018-1026

Shefrin, H. (2006). Beyond Greed and Fear: Understanding Behavioral Finance and the Psychology of Investing. Oxford University Press, Oxford.

Shin, H., \& Park, S. (2018). Do Foreign Investors Mitigate Anchoring Bias in Stock Markets? Evidence based on Post-Earnings Announcement Drift. Pacific Basin Finance Journal, 48, 224-240. https://doi.org/10.1016/j.pacfin.2018.02.008

Statman, M. S., Thorley, S., \& Vorkink, K. (2006). Investor Overconfidence and Trading Volume. Review of Financial Studies, 19(4), 1531-1565. https://doi.org/10.1093/rfs/hhj032

Syed, A. Z., \& Rohit, B. (2017). Do Investors Exhibit Behavioral Biases in Investment Decision Making? A Systematic Review. Qualitative Research in Financial Markets, 10(2), 210-251.

Syed, Z. A., Maqsood, A., \& Faisal, M. (2018). Heuristic Biases in Investment Decision- Making and Perceived Market Efficiency: A survey at the Pakistan Stock Exchange. Qualitative Research in Financial Markets, 10(1), 85-110. https://doi.org/10.1108/QRFM-04-2017-0033

Thaler, R. H. (1999). The End of Behavioral Finance. Financial Analysts Journal, 55(6), 12-17. https://doi.org/10.2469/faj.v55.n6.2310

\section{Copyrights}

Copyright for this article is retained by the author(s), with first publication rights granted to the journal.

This is an open-access article distributed under the terms and conditions of the Creative Commons Attribution license (http://creativecommons.org/licenses/by/4.0/). 